\title{
Soil Quality in the Poganis, Ramnei and Doclin Hills Measures of improvment
}

\begin{abstract}
LUCIAN NITA ${ }^{1}$, DORIN TARAU ${ }^{1}$, SIMONA NITA ${ }^{1 *}$, ALINA HEGHES ${ }^{2 *}$, RADU BERTICI ${ }^{1}$, DANIEL DICU ${ }^{1}$
'Banat University of Agricultural Sciences and Veterinary Medicine King Mihai I of Romania from Timisoara, 119, Calea Aradului, 300645, Timisoara, Romania

2Victor Babes University of Medicine and Pharmacy, Faculty of Pharmacy, 2 Eftimie Murgu Sq., 300041, Timisoara, Romania

The purpose of current research is part of the current scientific work and practice regarding the accumulation of knowledge on the structure and characteristics of the edaphic envelope and its quality in order to establish measures for its improvement. The researched issue covers an area of 113940 ha (of which 77039 ha, 67.61\% are agricultural land), located in the Poganis, Ramnei and Doclin hills, namely Barzavei Plain. The paper provides basic information and methodological elements regarding the classification and evaluation of soil resources, thus integrating itself in the broader field of complex studies of natural resources and their valorisation thus assuring the environmental protection. This research takes place at a time when there is a high demand of education in soil-related issues from its perspective as a basis for the existence of human communities, component and support of terrestrial ecosystems. From this perspective, the physicogeographic conditions of soil formation and evolution are briefly, but succinctly presented, mentioning the way in which the particularities of the area within the space taken into consideration, of only 113940 ha as a stretch, determine a great diversity of ecological conditions. They are generated by the variability of the factors (cosmic-atmospheric and telluric-edaphic), for which the main processes of formation and evolution have achieved a different development and intensity, the result of which are different genetic types of soils (related or totally different) in constant evolution and demanding specific improvement measures.
\end{abstract}

Key words: soil, quality, hills, improvement

FAO's 2018 World Food and Nutrition Status Report indicates that there is a direct link between soil health (soil quality and functionality) and the health status of food (plants, animals). The effect of soil properties on human health can be both positive and negative.

A healthy food grown on agricultural soils should contain seven macro elements ( $\mathrm{Na}, \mathrm{K}, \mathrm{Ca}, \mathrm{Mg}, \mathrm{S}, \mathrm{P}, \mathrm{Cl}$ ) and seventeen micro elements ( $\mathrm{Fe}, \mathrm{Zn}, \mathrm{Cu}, \mathrm{Mn}, \mathrm{I}, \mathrm{F}, \mathrm{B}, \mathrm{Se}, \mathrm{Mo}$, $\mathrm{Ni}, \mathrm{Cr}, \mathrm{Si}, \mathrm{Ca}, \mathrm{Li}, \mathrm{Sn}, \mathrm{V}, \mathrm{Co})$. Human food made up of plants and animals grown on poor soil deficient in these essential nutrients and affects negatively human health and wellbeing.

Therefore, the bioavailability of these elements needs to be strengthened in agroecosystems through a judicious management of the physical, chemical, biological and ecological properties of the soil. Improving soil health by replenishing organic matter through integrated fertility management can improve the nutritional value of food products based on the concept of a strong link between soil and human health, on the one hand, and environmental health and economic development, on the other hand.

Numerous studies and research at the national level have shown that there are interdependence relations between the agricultural technology systems of plant cultivation, the state of the environment, the level of economic development and the quality of life [1-3] which is why a responsible intervention on behalf of the state is necessary by providing the necessary funds for such programs.

Taking into consideration these aspects, our data from the paper is based on the pedological information existing in the OSPA archive in Timisoara, [4] the largest on classical support, as well as on the SPED1 information system and the BDUST-B system implemented in the territory by ICPA Bucharest, but also on the basis of the research carried out in time by the authors (OSPA, USAMVB) [5-7]. The paper contains some aspects related to pedoclimatic characteristics as elements defining fertility and soil quality in order to provide field users with specialized support for establishing the requirements and improvementmeasures in relation to the particularities of the space taken in consideration [8-11].

\section{Experimental part}

\section{Material and methods}

Our research issue covers an area of 113940 ha (table 1) out of which 77039 ha $(67.61 \%)$ are agricultural land ( 41494 ha respectively $36.41 \%$ being arable land) and 30826 ha $(27.05 \%)$ land with forest vegetation, situated in the upper and middle course of Beregsau, which from the administrative point of view, belongs to 12 territorial administrative units (TAU), one in Caras-Severin County.

The research of the ecopedological conditions has been done according to the Methodology of Elaboration of Pedological Studies [5,6,12,13] and other normative acts updated by MAAP Order $223 / 2002$, respectively Order MADR $278 / 2011$, based on the pedological information from the OSPA archive in Timisoara (for more than 65 years), but also on the basis of the research carried out in time by the authors (within OSPA, USAMVB Timisoara) $[4,12]$. The latter studies have been completed with recently collected items from the field.

\footnotetext{
*email: simona_nita@usab-tm.ro, Phone:0746543019; heghes.alina@umft.ro
} 
Table 1

SITUATION OF THE LAND FUND IN THE POGANISULUI, RAMNEI AND DOCLIN HILLS, BARZAVEI PLAIN.

\begin{tabular}{|c|c|c|c|c|c|c|c|c|c|c|c|}
\hline $\begin{array}{l}\mathrm{N} \\
\mathrm{o} .\end{array}$ & Locality & \begin{tabular}{c|} 
Arable \\
land
\end{tabular} & Pastures & Meadows & Vineyard & Orchards & \begin{tabular}{c|} 
Total \\
agricultural \\
land \\
\end{tabular} & Forests & $\begin{array}{c}\text { Rivers } \\
\text { and } \\
\text { lakes }\end{array}$ & \begin{tabular}{|c|}
$\begin{array}{c}\text { Other } \\
\text { categorie } \\
s\end{array}$ \\
\end{tabular} & Total \\
\hline 1 & Berzovia & 7723 & 2269 & 128 & 75 & 100 & 10295 & 1830 & 104 & 846 & 13075 \\
\hline 2 & Brebu & 1318 & 1510 & 673 & 0 & 597 & 4098 & 2933 & 32 & 392 & 7455 \\
\hline 3 & $\begin{array}{l}\text { Constantin } \\
\text { Daicoviciu }\end{array}$ & 2323 & 1694 & 158 & 1 & 453 & 4629 & 7727 & 128 & 531 & 13015 \\
\hline 4 & Copacele & 1090 & 1566 & 711 & 0 & 1 & 3368 & 1563 & 6 & 221 & 5158 \\
\hline 5 & Doclin & 3382 & 1677 & 315 & 516 & 135 & 6025 & 4080 & 60 & 388 & 10553 \\
\hline 6 & Farliug & 4039 & 4197 & 1881 & 0 & 155 & 10272 & 2127 & 61 & $\mathbf{5 8 7}$ & 13047 \\
\hline 7 & Forotic & 2381 & 3835 & 489 & 0 & 338 & 7043 & 2229 & 81 & 426 & 9779 \\
\hline 8 & Maureni & 7783 & 1364 & 231 & 0 & 0 & 9378 & 332 & 34 & 356 & 10100 \\
\hline 9 & Ramna & 2836 & 3649 & 191 & 0 & 282 & 6958 & 2180 & 37 & 424 & 9599 \\
\hline 10 & Sacu & 2417 & 691 & 128 & 0 & 61 & 3297 & 460 & 108 & 253 & 4118 \\
\hline 11 & Vermes & 4827 & 2463 & 161 & 0 & 256 & 7707 & 3273 & 50 & 411 & 11441 \\
\hline 12 & Zorlentu Mare & 1375 & 1967 & 367 & 0 & 260 & 3969 & 2092 & 20 & 519 & 6600 \\
\hline & TOTAL & 41494 & 26882 & 5433 & 592 & 2638 & 77039 & 30826 & 721 & $\mathbf{5 3 6 4}$ & 113940 \\
\hline & $\%$ total area & 36.41 & 23.59 & 4.78 & 0.52 & 2.31 & 67.61 & 27.05 & 0.63 & 4.71 & 100 \\
\hline & $\begin{array}{l}\text { total agricultural } \\
\text { land }\end{array}$ & 53.87 & 34.89 & 7.05 & 0.77 & 3.42 & 100 & - & - & - & - \\
\hline
\end{tabular}

\section{Results and dicussions}

The object of the current study is the area of 113940 ha (table 1) out of which 77039 ha are agricultural land (67.61\%) located in the Poganis, Ramnei and Doclin hills, namely the soil and ground units (TEO) identified in the perimeter where soils have been formed with a series of specific characteristics. These phenomena have taken place in close correlation with the variety of geomorphological factors that determine the existence of diversified relief units, of the geolithological and hydrological ones, as well as of the various anthropic interventions. As a result, some elements of that geographic space will be presented in the following part of the present study [14]

The Poganisului (Buziasului) hills, also known as the Sacos Hills, named after one of the oldest villages in the area, are a northwest continuation of Dognecei Mountains crystalline, over which the Sarmatian and Pontian deposits have been settled, represented by sandstone, marne, clay, and later heterogeneous deposits of pebbles and sands.

The Poganis hills are bordered to the north and east by the Timis river and to the south by Poganis (tributary of the Timis river), being known in the specialty literature as Buzias Hills, Sacos Hills or Sacos-Zagujeni Hills.

In the northwest, Buzias ascends a ridge of crystalline shale, whose foundation is east of Silagiu in the Dealul Scaunelor (324 m) or below the Blauca peak (355 m). To the southeast, over the crystal waters of Visag, the crystalline foundation appears on the surface in Magura Poenii (434 m).

The peaks are in the form of large plateaus, lying around a 300-meter elevation, bordered by smooth slopes, partially eroded by the valleys of the tributaries of Timis and Poganis.

The Ramna Hills, located between Poganis Valley and Barzavei Valley, have a minimal extension, only a few divergent peaks that make the connection to the terraced plain, which is only 6-8 km far from the foothills of the Arenis Mountains, representing a great cone of dejection located at their foot, bordered by torrential structures and erosion valleys that have burst here since the end of the tertiary. Both the Pannonian pebbles and sands, as well as the banatites from the Arenis Mountains, are covered with a blanket of clay and Pleistocene clays.

Doclin Hills, bounded by the Barzava and Caras rivers, stretch from Bocsa to Secaseni, under the Dognecei
Mountains, separated from this massif by a denivelation that sometimes exceeds 200-400 m [7,10,11,15].

The peaks, which rarely exceed $200 \mathrm{~m}$ in altitude (237 $\mathrm{m}$ Teius), are separated by valleys with broad river meadows (Ciornovat, Caras and their tributaries).

As in the case of the above-mentioned hills, the substrate made of lightweight rocks (sands, gravel, etc.) is covered with Pleistocene clays.

The Barzavei Plain is a piedmont plain that was born through the deposition of poorly terraced glaciers, and fractured in the shape of a fan by the waters that cross it, dividing it into several fields: Poganisului Plain (to the north of Poganis) Sipet- Gataia (between Poganis and Barzava) Semlacului Plain (between Barzava and Moravita) Campia Clopodiei (southwest at the foot of Doclin Hills). The plain descends gradually, from the Dognecei Hills area, from altitudes ranging from $160-170 \mathrm{~m}$ to $100-110 \mathrm{~m}$ to the region of subsidence and ends quite abruptly, in the low plain on the line of Latunas-J amu Mare-Moravita-Gaiu MicDenta-Opatita-Folea-Liebling-Sacosu-Buzias. Overall, it is a piedmont plain with flat interfluves, fragmented by wide diverging valleys.

Due to the pedo-hydro-climatic and floristic conditions, as well as to the human intervention (starting with the preRoman period and up to now), the soils in the researched area show a great diversity, according to the Romanian Soil Taxonomy System (SRTS-2012) 12 soil types have been identified: Litosoils, Aluviosoils, Faeisomes, Eutricambosoils, Preluvosoils, Luvosoils, Vertosoils, Stagnosoils, Gly-soills and Antrosoils (table 2) comprising 7 of the 12 soil classes (Protisoils, Cernisoil, Cambisoils and Antrisoil).

In the context of the information presented so far, the quality of agricultural lands, as a result of the diversity of physical and geographical conditions and their intrinsic attributes, as well as of the anthropogenic interventions occurring in time, presents many differences in the area. That is why the Romanian methodology for the evaluation of agricultural lands that includes the synthesis of specialized knowledge [13], defines the land in ecological terms in relation to the cosmic-atmospheric and technicaledaphic factors.

The basic principle of the assessment methodology developed in our country is the following: for each unit of 
Table 2

THE MAIN TYPES AND ASSOCIATIONS OF SOILS IN THE POGANIS, RAMNEI AND DOCLIN HILLS. BARZAVEI PLAIN

\begin{tabular}{|c|c|c|c|c|c|c|c|c|c|c|c|c|c|c|c|c|c|}
\hline \multirow[t]{2}{*}{ No. } & \multirow{2}{*}{$\begin{array}{l}\text { Territorial- } \\
\text { adminstrative } \\
\text { Unit }\end{array}$} & \multirow{2}{*}{$\begin{array}{l}\text { Agri } \\
\text { ha }\end{array}$} & \multicolumn{15}{|c|}{ Type, subtype of soil } \\
\hline & & & $\begin{array}{l}\text { l. } \\
\text { LS }\end{array}$ & $\begin{array}{l}2 . \\
\text { RS }\end{array}$ & $\begin{array}{l}3 . \\
\text { AS }\end{array}$ & $\begin{array}{l}4 . \\
\text { FS }\end{array}$ & $\begin{array}{l}5 . \\
\text { EC }\end{array}$ & $\begin{array}{c}6 . \\
\text { DC }\end{array}$ & $\begin{array}{c}7 . \\
\text { EL }\end{array}$ & $\begin{array}{l}8 . \\
\text { LV }\end{array}$ & $\begin{array}{l}9 . \\
\text { PL }\end{array}$ & $\begin{array}{l}10 . \\
\text { VS }\end{array}$ & $\begin{array}{l}\text { l1. } \\
\text { PE }\end{array}$ & SG & $\begin{array}{l}13 . \\
\text { GS }\end{array}$ & $\begin{array}{l}14 . \\
\text { AT }\end{array}$ & $\begin{array}{l}15 . \\
\text { Asc }\end{array}$ \\
\hline 1 & Berzovia & 10295 & - & - & - & 409 & 1269 & - & - & 6273 & 469 & 113 & 106 & 69 & 724 & 174 & 659 \\
\hline 2 & Brebu & 4093 & - & - & 883 & 398 & 338 & - & - & 825 & 708 & - & - & 295 & 38 & 563 & - \\
\hline 3 & $\begin{array}{l}\text { Constantin } \\
\text { Daicoviciu }\end{array}$ & 4629 & - & - & 93 & 926 & 602 & - & - & 278 & 1481 & - & & 370 & 185 & 139 & 555 \\
\hline 4 & Copacele & 3365 & - & - & 51 & 44 & 68 & - & - & 88 & 657 & 101 & - & 30 & 30 & 54 & 2245 \\
\hline 5 & Doclin & 6025 & - & - & - & 136 & 224 & - & 142 & 763 & 4554 & - & - & - & - & - & 206 \\
\hline 6 & Farliug & 10272 & - & - & 361 & 1062 & 792 & - & 102 & 1882 & 4763 & - & - & 5 & 10 & 1295 & - \\
\hline 7 & Forotic & 7043 & $=$ & - & - & 705 & 611 & - & - & 995 & 1427 & - & 211 & 749 & 352 & 1033 & 960 \\
\hline 8 & Maureni & 9373 & - & - & - & 331 & 720 & - & - & 5536 & 185 & 113 & 454 & 1032 & 477 & 530 & - \\
\hline 9 & Ramna & 6958 & 323 & - & 406 & 669 & 821 & - & 290 & 1872 & 2286 & - & 66 & - & - & - & 225 \\
\hline 10 & Sacu & 3297 & - & - & - & 593 & 231 & - & - & 923 & 1153 & - & - & 165 & 164 & 68 & - \\
\hline 11 & Vermes & 7707 & - & - & - & 701 & 210 & - & - & 2004 & 2496 & - & 351 & 68 & 360 & 1050 & 467 \\
\hline 12 & \begin{tabular}{|l|} 
Zorlentu \\
Mare \\
\end{tabular} & 3969 & - & - & 90 & 192 & 280 & - & - & 1725 & 962 & - & 90 & 120 & 60 & 460 & - \\
\hline \multicolumn{2}{|c|}{ Caras-Severin } & 77039 & 323 & - & 1874 & 6166 & 6166 & - & 534 & 23164 & 21141 & 327 & 1278 & 2903 & 2450 & 5366 & 5347 \\
\hline \multicolumn{2}{|c|}{$\begin{array}{l}\text { So out of the } \\
\text { total agricultural } \\
\text { land }\end{array}$} & 100 & 0.42 & - & 2.44 & 7.98 & 8.00 & - & 0.69 & 30.07 & 27.44 & 0.43 & 1.66 & 3.78 & 3.18 & 6.97 & 6.94 \\
\hline
\end{tabular}

homogeneous ecological territory (HET) within a territorial administrative unit (TAU), defined according to the current Methodology for Development of Pedological Studies using the 23 indicators which are usually found in the pedological mapping w orks developed after 1987 by the territorial OSPA under the methodological guidance of ICPA Bucharest, its quality is established by grades from 1 to 100 .

Each of the identified units within the investigated area was characterized according to the Methodology of Elaboration of Pedological Studies [5], using the 23 indicators, namely climatic indicators (indicator $3 \mathrm{C}$ average annual temperature - corrected values, indicator 4C- average annual precipitation - corrected values), indicators of morphological, chemical, physical, hydrophysical characteristics and volume of soil cover (indicator 14 - gleaning, indicator 15 - stagnogleization, indicator 16 or 17 - salinisation or alkalisation (indicator 61 - total $\mathrm{CaCO}_{3}$ content on $0-50 \mathrm{~cm}$, indicator 63 - soil reaction in Ap or the first $20 \mathrm{~cm}$, indicator 144 - humus reserve in the $0-50 \mathrm{~cm}$ layer, indicator $23 \mathrm{~A} \mathrm{-,} \mathrm{texture} \mathrm{in} \mathrm{Apor} \mathrm{first} 20 \mathrm{~cm}$, indicator 44 - total porosity in the restrictive horison, indicator 44 . total porosity in the restrictive horison, indicator 133 - the usable edaphic volume), indicators of the relief characteristics (indicator 33 - slope, indicator 38 landslides), hydrography, hydrology and drainage indicators (indicator 40 - floodability, indicator 181 - excess humidity, indicator 39 - pedo-ground water depth), indicators relating to some anthropic interventions (indicator 29 - pollution indicator 271 - land improvement approaches), as well as interactions between these values of characterisation of natural and anthropically induced properties.

Therefore, on the basis of pedological information processed according to the Methodology for the Development of Pedological Studies [5] and other normative acts updated by Order MADR278 / 2011, the agricultural lands of the researched area can be grouped (from 20 to 20 points) in V classes (quality) according to their vocation for arable use (table 3).

The operation of classifying agricultural land in quality classes based on the assessment marks highlighted a series of limiting factors that influence the agricultural production capacity, within the researched area among which we mention: the granulometric composition (soil texture), the reserve of humus, soil reaction, compaction

Table 3

CLASSES FOR THE USE OF ARABLE LAND (HA) IN THE POGANIS, RAMNEI AND DOCLIN HILLS. BARZAVEI PLAIN

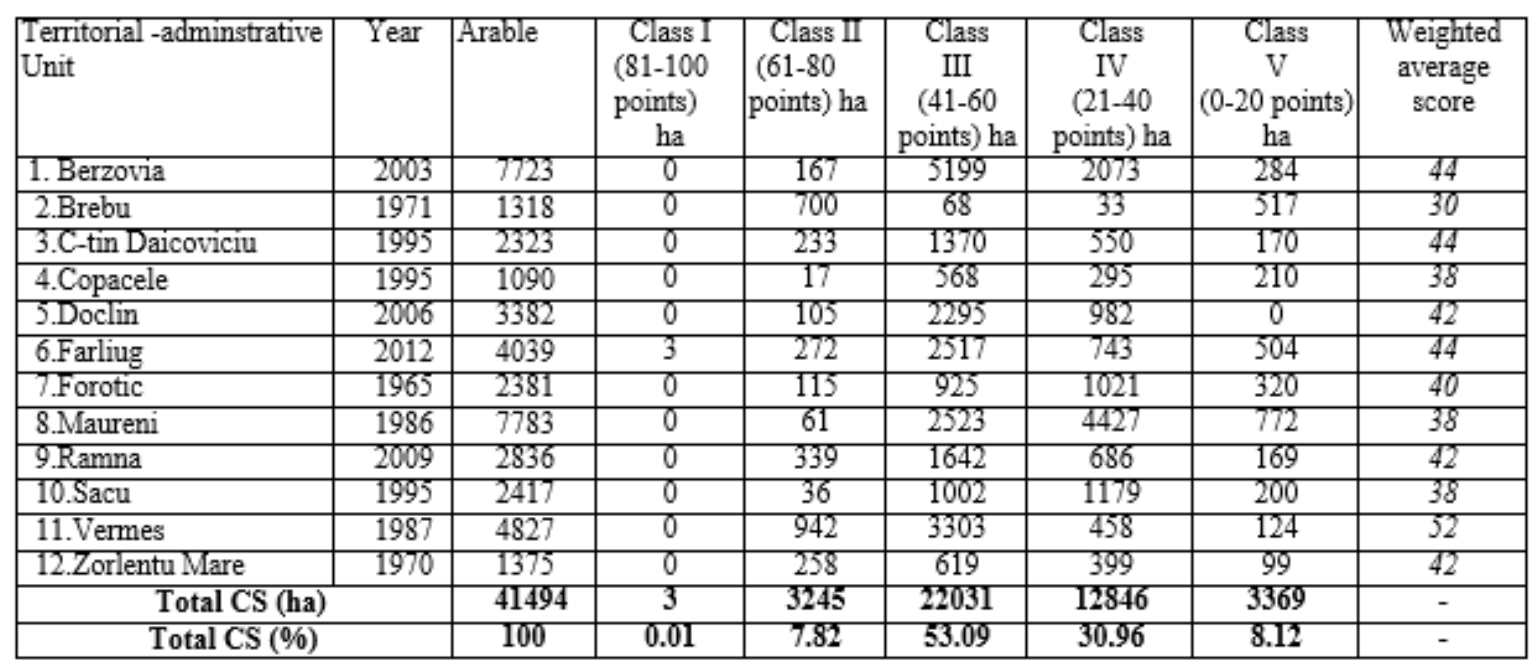


Table 4

SITUATION OF FIELDS WITH SURFACE AND GROUNDWATER HUMIDITY EXCESS WIN THE POGANISULUI, RAMNEI AND DOCLINULUI HILLS. THE BARZAVEI PLAIN.

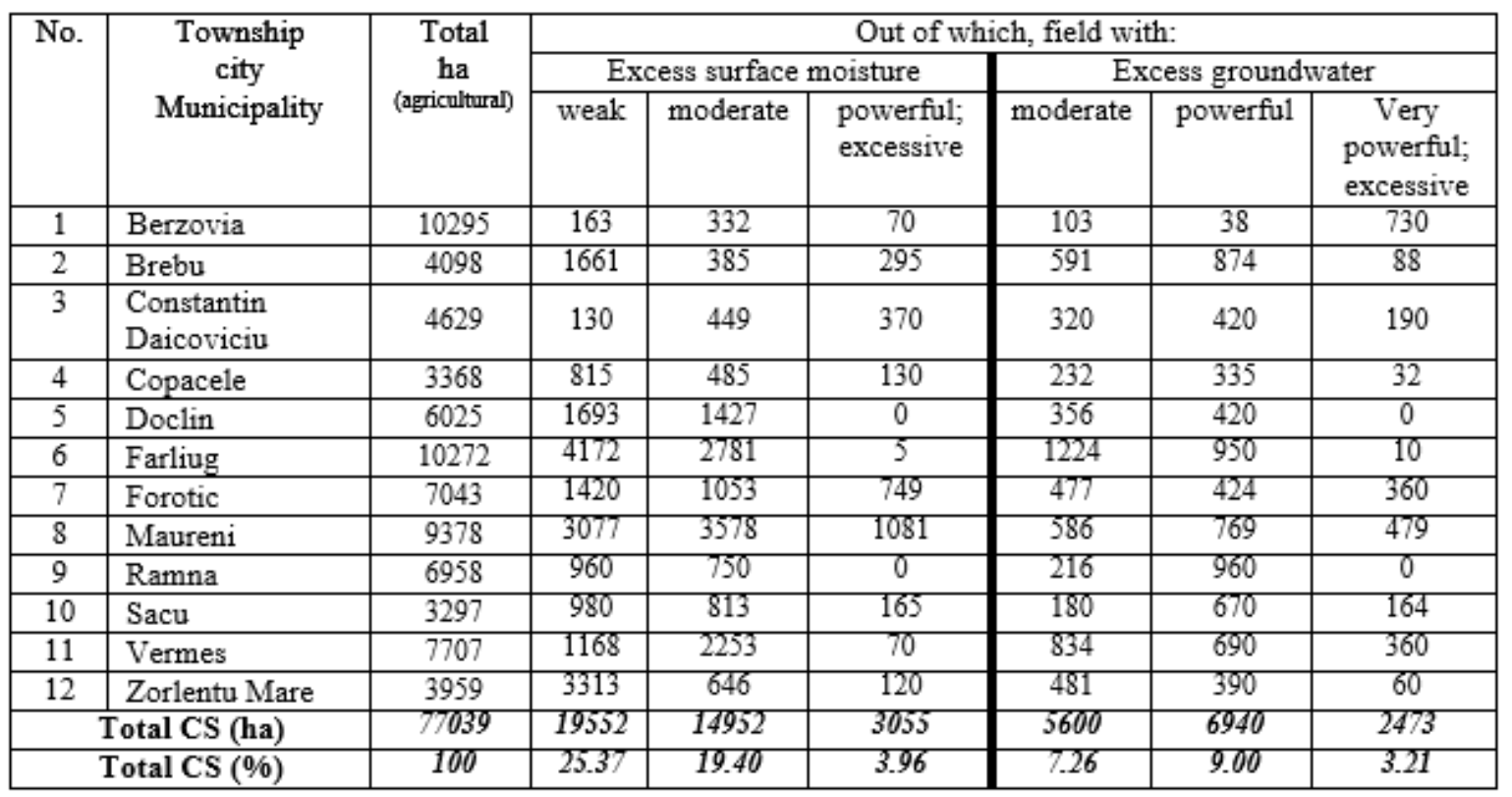

Table 5

SITUATION OF LAND AFFECTED BY COMPACTING AND ACIDIFICATION IN THE POGANISULUI, RAMNEI AND DOCLINULUI HILLS. BARZAVEI PLAIN

\begin{tabular}{|c|c|c|c|c|c|c|c|c|}
\hline \multirow[t]{3}{*}{ No. } & \multirow{3}{*}{$\begin{array}{c}\text { Township } \\
\text { city } \\
\text { Municipality }\end{array}$} & \multirow{3}{*}{$\begin{array}{c}\text { Total } \\
\text { ha } \\
\text { (agriculure) }\end{array}$} & \multicolumn{6}{|c|}{ Out of which fields with: } \\
\hline & & & \multicolumn{3}{|c|}{ compacting } & \multicolumn{3}{|c|}{ acidification } \\
\hline & & & weak & moderate & $\begin{array}{l}\text { powerful } \\
\text { excessive }\end{array}$ & weak & moderate & $\begin{array}{l}\text { powerful } \\
\text { excessive }\end{array}$ \\
\hline 1 & Berzovia & 10295 & 3130 & 2999 & 2680 & 3420 & 3108 & 450 \\
\hline 2 & Brebu & 4098 & 1394 & 1341 & 1190 & 1435 & 1877 & 810 \\
\hline 3 & $\begin{array}{l}\text { Constantin } \\
\text { Daicoviciu }\end{array}$ & 4629 & 1105 & 2064 & 1281 & 1575 & 1530 & 845 \\
\hline 4 & Copacele & 3368 & 690 & 1249 & 1096 & 813 & 2064 & 625 \\
\hline 5 & Doclin & 6025 & 2410 & 2100 & 990 & 2056 & 1946 & 1680 \\
\hline 6 & Farliug & 10272 & 2944 & 2743 & 1220 & 3199 & 1925 & 2212 \\
\hline 7 & Forotic & 7043 & 1420 & 1053 & 500 & 2655 & 642 & 960 \\
\hline 8 & Maureni & 9378 & 7385 & 2316 & 296 & 2792 & 1836 & 1025 \\
\hline 9 & Ramna & 6958 & 2560 & 1197 & 790 & 2234 & 250 & 1860 \\
\hline 10 & Sacu & 3297 & 1210 & 924 & 242 & 1428 & 1228 & 824 \\
\hline 11 & Vermes & 7707 & 4311 & 1182 & 960 & 3978 & 1341 & 1680 \\
\hline 12 & Zorlentu Mare & 3969 & 1533 & 1626 & 640 & 1623 & 1059 & 790 \\
\hline \multicolumn{2}{|c|}{ Total CS (ha) } & 77039 & 30092 & 20794 & 11885 & 27208 & 18806 & 13761 \\
\hline \multicolumn{2}{|c|}{ Total CS (\%) } & 100 & 39.06 & 26.99 & 15.43 & 35.32 & 24.41 & 17.86 \\
\hline
\end{tabular}

degree or compactness, excess humidity, some of which are exemplified by the affected areas (tables 4-5).

The limiting factors that affect the potential soil cover within this area, is mainly referring to limitations due to excess of stagnant humidity and groundwater (table 4), soil acidification (table 5) and compaction degree (compression) facts for which it is being imposed, on a case-by-case basis, pedo-hydro-ameliorative (desiccation, drainage, deep raising, etc.) for the achievement of a balanced aero-hydric regime and of measures that would favor the conduct of the concentration of the nutritive elements and those of the within the soil organic matter (ameliorative fertilization, long-lasting planting with herbaceous plants and perennial grasses, etc.).

All the measures aimed at raising soil quality will take in account the pursuit of the procedures, leading to the concentration of nutrients and organic matter. In order for the physical degradation of the soil to be prevented, it is necessary to minimize its preparation works, to perform the agrotechnical works at the optimal humidity, as well as to ensure an adequate structure of the ameliorative plant crops.

Taking in account that a good part of the township's soils of the agricultural terrain are being affected during the vegetation period of humidity excess, which negatively affect the agricultural productions, the specific technologies will equally aim at increasing the aeration porosity as well as the water's permeability, through deeplying work, associated with agrotechnical works executed at the right time and of good quality.

Referring to the acid soils these occupy within the researched field a surface of ha within the agricultural fields (table 5), thus grouped according to the acidification's intensity: weak-pH between 5,8-6,8 moderate-pH between 5,1-5,8, strong-excessive with $\mathrm{pH}$ value under 5,1 .

These soils present a common characteristics, respectively the low $\mathrm{pH}$ values could be, based on the type of the soil-formation, separated in two big groups, with implication on the aerodynamic regime, respectively 
Table 6

ALPINE-STAGNANT LUVOSOIL, MEDIUM CLAY / MEDIUM CLAYEY CLAY, FARLIUG, CARAS-SEVERIN COUNTY

\begin{tabular}{|c|c|c|c|c|c|c|c|c|}
\hline Honizons & UM & Alow $_{2}$ & $\mathrm{AEw}_{3}$ & $\mathrm{Eaw}_{4}$ & $\mathrm{BtW}$ & $\mathrm{Btw}_{3}$ & $\mathrm{BC}$ & $\mathrm{C}$ \\
\hline Depth & $\mathrm{cm}$ & $0-18$ & -45 & -65 & -81 & -110 & -137 & -164 \\
\hline Coarse sand $(2.0-0.2 \mathrm{~mm})$ & $\%$ & 5.4 & 6.3 & 9.6 & 4.1 & 1.9 & 3.4 & 4.2 \\
\hline Fin sand $(0.2-0.02 \mathrm{~mm})$ & $\%$ & 41.4 & 40.5 & 38.2 & 32.0 & 31.7 & 32.1 & 32.4 \\
\hline Dust $(0.02-0.002 \mathrm{~mm})$ & $\%$ & 31.6 & 32.8 & 32.1 & 30.7 & 26.7 & 29.2 & 35.9 \\
\hline Colloidal clay ( under $0.002 \mathrm{~mm}$ ) & $\%$ & 21.6 & 20.4 & 20.1 & 33.2 & 39.7 & 35.3 & 275 \\
\hline Physic clay (under $0.01 \mathrm{~mm}$ ) & $\%$ & 37.6 & 37.5 & 36.5 & 47.0 & 52.3 & 50.7 & 48.7 \\
\hline TEXTURE & & LL & SS & SM & TT & TT & TT & $\mathrm{LP}$ \\
\hline Apparent density (Da) & $\mathrm{g} / \mathrm{cm}^{3}$ & 1.29 & 1.53 & 1.68 & 1.69 & - & - & - \\
\hline Specific density (Ds) & $\mathrm{g} / \mathrm{cm}^{3}$ & 2.61 & 2.64 & 2.66 & 2.70 & - & - & - \\
\hline Porosity of aeration (PA) & $\%$ & 23.7 & 13.8 & 5.6 & 0.4 & - & - & - \\
\hline Degree of compression ( GT) & $\%$ & -5.1 & 11.0 & 23.3 & 24.1 & - & - & - \\
\hline Hygroscopicity coefficient ( $\mathrm{CH}$ ) & $\%$ & 5.1 & 4.8 & 4.7 & 7.3 & - & - & - \\
\hline Coefficient of wilting $(\mathrm{CO})$ & $\%$ & 7.6 & 7.2 & 7.1 & 11.0 & - & - & - \\
\hline Field capacity (CC) & $\%$ & 21.2 & 19.1 & 18.7 & 22.4 & - & - & - \\
\hline Total capacity (CT) & $\%$ & 39.5 & 28.1 & 22.0 & 22.5 & - & - & - \\
\hline Usable water capacity (CU) & $\%$ & 13.6 & 11.9 & 11.6 & 11.4 & - & - & - \\
\hline Hydraulic conductivity (K) & $\mathrm{mm} / \mathrm{h}$ & 8.6 & 3.1 & 1.2 & 0.4 & - & - & - \\
\hline $\mathrm{pH}$ in water & & 5.27 & 5.33 & 5.56 & 5.48 & 5.42 & 5.78 & 6.30 \\
\hline Humus & $\%$ & 2.73 & 2.02 & 0.73 & - & - & - & - \\
\hline Azote index (IN) & & 1.51 & 1.11 & 0.41 & - & - & - & - \\
\hline Humus reserve & to/ha & 63.4 & 83.4 & 6.1 & 152.9 & - & - & - \\
\hline Mobile Phosphorus (P mobile) & $\mathrm{ppm}$ & 43.2 & 36.0 & 34.8 & - & - & - & - \\
\hline Mobile Potassium (K mobile) & $\mathrm{ppm}$ & 132 & 118 & 110 & - & - & - & - \\
\hline Exchange bases (SB) & $\mathrm{me} / 100$ & 10.29 & 8.79 & 8.14 & 11.36 & 15.65 & 17.37 & 17.16 \\
\hline Changeable hydrogen (SH) & $\mathrm{me} / 100$ & 8.25 & 7.12 & 6.05 & 5.94 & 6.92 & 4.97 & 3.23 \\
\hline Cationic exchange capacity (T) & $\mathrm{me} / 100$ & 18.54 & 1591 & 14.19 & 17.30 & 22.57 & 22.34 & 20.39 \\
\hline Saturation degree in bases (V) & $\%$ & 55.50 & 55.24 & 57.36 & 65.66 & 69.34 & 77.75 & 84.16 \\
\hline Mobile aluminum & $\mathrm{me} / 100$ & 0.48 & - & - & - & - & - & - \\
\hline
\end{tabular}

SHADOW DISTRICAMBOSOIL, MEDIUM SAND / MIDDLE CLAY, FARLIUG, JUDETUL CARAS-SEVERIN

\begin{tabular}{|l|c|c|c|c|c|c|c|}
\hline Horizons & UM & At & Auw & Bvw & BC & $\mathrm{C}_{1} \mathrm{q}_{2}$ & $\mathrm{C}_{2} \mathrm{q}_{2}$ \\
\hline Depth & $\mathrm{cm}$ & $0-7$ & -43 & -85 & -120 & -140 & -165 \\
\hline Coarse sand (2.0-0.2 mm) & $\%$ & 17.0 & 15.0 & 13.4 & 31.2 & 31.4 & 24.2 \\
\hline Fine sand (0.2-0.02 mm) & $\%$ & 34.9 & 32.4 & 32.8 & 32.8 & 16.6 & 18.4 \\
\hline Dust (0.02-0.002 mm) & $\%$ & 31.7 & 33.7 & 32.3 & 23.5 & 14.2 & 5.2 \\
\hline Colloidal clay (under 0.002 mm) & $\%$ & 16.4 & 18.9 & 21.5 & 12.5 & 7.8 & 7.2 \\
\hline Physical clay (under 0.01 mm) & $\%$ & 32.4 & 35.5 & 38.3 & 27.9 & 15.5 & 10.4 \\
\hline TEXTURE & - & SM & SS & LL & SM & UG & UG \\
\hline Skeleton & $\%$ & - & - & - & - & 30 & 45 \\
\hline Apparent density (Da) & $\mathrm{g} / \mathrm{cm}^{3}$ & 1.28 & 1.43 & 1.51 & - & - & - \\
\hline Specific density (Ds) & $\mathrm{g} / \mathrm{cm}^{3}$ & 2.61 & 2.67 & 2.69 & - & - & - \\
\hline Total porosity (PT) & $\%$ & 51 & 47 & 44 & - & - & - \\
\hline Porosity of aeration(PA) & $\%$ & 26.0 & 20.0 & 14.7 & - & - & - \\
\hline Degree of compression(GT) & $\%$ & -7.0 & 2.2 & 9.3 & - & - & - \\
\hline Hygroscopicity coefficient(CH) & $\%$ & 3.9 & 4.5 & 5.1 & - & - & - \\
\hline Coefficient of wilting (CO) & $\%$ & 5.8 & 6.7 & 7.6 & - & - & - \\
\hline Field capacity (CC) & $\%$ & 19.5 & 18.9 & 19.4 & - & - & - \\
\hline Total capacity (CT) & $\%$ & 39.8 & 32.9 & 29.1 & - & - & - \\
\hline Usable water capacity (CU) & $\%$ & 13.7 & 12.2 & 11.8 & - & - & - \\
\hline Hydraulic conductivity (K) & $\mathrm{mm} / \mathrm{h}$ & 6.2 & 5.1 & 3.0 & - & - & - \\
\hline pH in Water & - & 5.35 & 5.22 & 5.31 & 5.89 & 7.03 & 7.09 \\
\hline Humus & $\%$ & 2.02 & 0.94 & 0.41 & - & - & - \\
\hline Azote index (IN) & - & 1.01 & 0.41 & 0.19 & - & - & - \\
\hline Humus reserve & to ha & 18.1 & 48.4 & 4.3 & 70.8 & - & - \\
\hline Mobile Phosphorus (P mobile) & $\mathrm{ppm}$ & 43.2 & 40.8 & - & - & - & - \\
\hline Mobile Potassium (K mobile) & $\mathrm{ppm}$ & 110 & 105 & - & - & - & - \\
\hline Change bases (SB) & $\mathrm{me} / 100$ & 6.61 & 5.15 & 6.19 & 10.57 & - & - \\
\hline Changeable hydrogen (SH) & $\mathrm{me} / 100$ & 6.58 & 6.47 & 6.88 & 3.70 & - & - \\
\hline Cationic exchange capacity (T) & $\mathrm{me} / 100$ & 13.19 & 11.62 & 13.07 & 14.27 & - & - \\
\hline Saturation degree in bases (V) & $\%$ & 50.11 & 44.32 & 47.36 & 74.07 & - & - \\
\hline Mobile aluminum & $\mathrm{me} / 100$ & - & 0.92 & - & - & - & - \\
\hline & & & & & & & - \\
\hline
\end{tabular}

the first group brings the soil types that have horizon $\mathrm{B}$ argiloluvial (Bt): Preluvosoil, Luvosoils (table 6), Planosoil, Stagnosoil together and the second, soils with horizon $B$ cambic (Bv) Districambosoils (table7).

Taking in account the bioclimatic zone and the material on which it was formed (table 2) the reaction presents, on large zones, some specific characteristics, indicating inappropriate anthropogenic interventions. The Low pH values in the processed layer indicate rather high debase ( $p H: 5.8-6.8)$, caused, in the researched space, by repeated fertilization with fertilizer with acid reaction, on a surface ha (table 5), in this table, while presenting data referring to 
the surface with acid soils within in the researched space administrative territorial repartition.

The purpose of the present analysis is to offer to the deciding person an image on the territorial repartition of the acid soils, knowing these aspects could represent a great theoretical and practical importance.

It has a theoretical value because it offers the specialist the possibility to interpret the phenomena that take place within the natural resources and to forecast their evolution, in particular, and of the environment, in general, from the current and future health point of view. The practical importance is given by the fact that it warns the practitioner on the measures that should be taken so that these resources are being brought to optimal conditions for the harvested or spontaneous plant's development and growth. Acidity, expressed through the current acidity $(\mathrm{pH})$ and titratable (of change and hydrolytic) expressed acidity, causes a high density of hydrogen ions in the soil solution as well as of hydrogen and aluminum ions absorbed in the colloidal complex, that directly affect the by the root system developed plant's nutritional process.

The acidity profoundly influences the metabolism process itself, through disorder of the formation of the protean substance, because of which, the nitrogenous substances remain at the within the route accumulated aminoamides.

The damaging effects of acidity have indirect implications as well.

The surface of the colloidal particles are saturated with $\mathrm{H}^{+}$, solubilizes the Al hydroxides with release of an aluminum ionic complex in the solution, which at the end is absorbed into a complex and blocks the permanent negative loads of the silicate layers so that the total capacity value of effective change (Tef) varies between 6-57 me/ $100 \mathrm{~g}$ soil.

The mobile forms of aluminum in the soil, Type $\mathrm{Al}^{3+}$ $\mathrm{Al}(\mathrm{OH})^{2+}, \mathrm{Al}(\mathrm{OH})_{2}{ }^{+}$have a strong negative effect on the phosphorus and molybdenum mobility. Soluble monophosphate ions from the phosphor fertilizers $\left(\mathrm{H}_{2} \mathrm{PO}\right.$ $\left.{ }_{4}\right)$, the only ones that form out of salts of phosphoric acid in soil with strong acid are easy to be absorbed on the surface electropositive charge of the aluminum hydroxide.

$$
\mathrm{Al}(\mathrm{OH})^{+}{ }_{2}+\mathrm{H}_{2} \mathrm{PO}_{4}^{-} \rightarrow \mathrm{Al}(\mathrm{OH})_{2} \mathrm{H}_{2} \mathrm{PO}_{4}
$$

the typical reaction to fixate the anions through the protonic mechanism [11].

The soluble phosphates suffer however within the soil and the insolubilization process through chemical retain, so that the phosphate cannot be anymore assimilated by plants:

$$
\mathrm{Al}(\mathrm{OH})_{3}+\mathrm{H}_{3} \mathrm{PO}_{4} \rightarrow \mathrm{AlPO}_{4}+3 \mathrm{H}_{2} \mathrm{O}
$$

Through the reactions of absorption and precipitation it is much more reduced in the acid soils and the mobility of ions of molybdian $\mathrm{MoO}^{-}$, which explains the molybdenum deficiency. The aluminum ions present in the soil solution worsen de ions' absorption of potassium, calcium, magnesium and ammonium, because the initial ions absorption on the surface of the radicular hairs is proportionate with the rapport between the active concentration of those ions in the soil solution.

This deficiency in the absorption of potassium, calcium, magnesium and ammonium explains as well the chemical fertilization of the acid soils. A Aluminum concentration of even 1-2ppm is toxic for the majority of the harvested plants [15]. Corresponding to the equation:

$$
\mathrm{pAlm}=2 \mathrm{pH}-4.41
$$

so that for a concentration of aluminum in the soil of 108 $\mathrm{ppm}, 43 \mathrm{ppm}$ and $1.7 \mathrm{ppm}$ the $\mathrm{pH}$ values reach 3.4,3.6 and 4.3.

The negative effect of the mobile forms of aluminum in soil, could be eliminated through the raise of the $\mathrm{pH}$ value through the effect of limestone or the submersion of the soil in a few weeks before the beginning of harvesting. The danger, in case of humidity excess is the surface of the $\mathrm{Fe}^{2+}$ ions [15].

$$
\begin{gathered}
E h=1.058-0.059 \lg \mathrm{Fe}^{2+}-0.177 p H \\
p E=17.87+p F e^{2+}-3 p H
\end{gathered}
$$

The toxicity of iron can be limited as well through the appearance of limestones and $\mathrm{MnO}$ addition. Calcium carbonate increases the $\mathrm{pH}$ and decreases the $\mathrm{Fe}^{2+}$ concentration in water. Manganese stops the reduction, lowers the $\mathrm{Fe}^{2+}$ concentration and eliminates the ion's toxic effect contrary to iron.

On the heavy acid soils even manganese can accumulate in big quantities, under a bivalent form, becoming as such toxic for the plants, especially during the periods with excess water. An indirect negative effect on the growth of the harvested plants on acid soils this being determined by the reduction of the azote and nitrifications fixing microorganism's activity whose optimal should be found with the $\mathrm{pH}$ limits of 6.5-7.5.

Instead, the activity of cellulosic bacteria and actinomycetes is stimulated which develops well and at a $\mathrm{pH}$ de 4-5. In acid soils and anaerobiosis caused by water stagnation reduction phenomena take place [15].

$$
\begin{gathered}
4 \mathrm{Fe}(\mathrm{OH})_{3}+4 \mathrm{CaSO}_{4}+9 \mathrm{CH}_{2} \mathrm{O}= \\
=4 \mathrm{FeS}+4 \mathrm{Ca}\left(\mathrm{HCO}_{3}\right)_{2}+\mathrm{CO}_{2}+11 \mathrm{H}_{2} \mathrm{O} \\
\mathrm{FeS}+\mathrm{S}=\mathrm{FeS}_{2}
\end{gathered}
$$

The formed pyrite is oxidized through drainage until ferric sulfate and ferric hydroxide. Oxidation is all the more intense as the humidity decreases from 40 to $10 \%$. The over $0.15 \%$ in the acid and humid soil air accumulated carbon dioxide has as well a shrinking effect on the absorption of water and nutritive salts, limiting roots growth and even provoking wilting of plants.

Taking in account all these considerations depending on the concrete situation on a case-by-case bases, the with calcium periodic amendments of the soils bring to improvement nutrition conditions of the plants next to ameliorative fertilization and hydro-extraction works for draining and exhausting excess water (groundwater and precipitation).

Referring to the calcium amendment (known as calcification) generally is appreciated, that the need of calcium amendments, for optimizing reactions and the in bases saturation state, appear at soils with a $\mathrm{pH}<5.8$ and in base saturation degree $\mathrm{V}<75$ and the presence of interchangeable aluminum in easy measurable quantities (higher the 0.2-0.3 millimass equivalent at $100 \mathrm{~g}$ soil), for field plants with the exception of crop rotation of leguminous plantations and walnut and strawberry plantations. For leguminous crops, it is recommended the values of the $\mathrm{pH}$ to be amended below 6 and $\mathrm{V}$ below $80 \%$ [2].

The aluminum ion penetration into the roots and the manifestation of the phytotoxic effect is proportional with 
the rapport between the activity of the main ion species out of the acid soils solution $\left(\mathrm{Al}^{3+}\right)^{1 / 3} /\left(\mathrm{Ca}^{2+}+\mathrm{Mg}^{2+}\right)^{1 / 2}$, considering that the main ion species and the magnesium have an moderating effecton the Al, itcould be appreciated that the relation between $A 1$ and the sum of the exchangeable bases an added plus of certitude, because of which the phytotoxic effect of aluminum will differ in relation to the sum of the exchange bases, consisting predominantly of calcium and magnesium.

Depending on the requests of the harvested plants face to the reaction and the presence of calcium amending of calcium shall be recommended in relation with (AI/SB $x$ 100 ) in the harvested layer of soil exceeds 5 (crops without perennial leguminous) over 2.5 (crops with perennial leguminous ) or over 6 (in trees plantations -wine-growing).

The calcium carbonate doses should be higher than the equivalent of soil aluminum due to the following causes: uniform mixture of the amendment within the soil masses will be gradually achieved through multiple ploughings and disking, the uneven distribution of the amendment making the overdose necessary; dissolution of the amendment and neutralization of the acidity is developing in parallel with the profoundly leaching the bases and the ones to be consumed; loss of calcium within the amended soils are higher than the not amended ones, intensified once with the growth of the amended doses; the efficiency duration grows in parallel with the applied doses.

It is considered that neutralization of $3 / 4$ until $1 / 1 /$ of hydraulic acidity of the shows layer corresponds the correction, in practice the calculated doses with the relation $[9,10]$.

$$
\mathrm{CaCO}_{3} \mathrm{t} / \mathrm{ha}=\mathrm{SBi}\left(\frac{\mathrm{Vd}}{\mathrm{Vi}}-1\right) \times \mathrm{H}^{\times} 0.06 \times \frac{100}{P_{N A}}
$$

where: soil.

$\mathrm{SBi}$-initial amount of the exchange bases, me/100 g

$\mathrm{Vd}$-desired saturation degree (calculated with $\mathrm{Ah}$ ) to be achieved in soil and that has values: $100 \%$ for crops with perennial leguminous $90 \%$ for the rest of the field plants, walnuts and straw berries, $75 \%$ for trees plantations -wine-growing plantations and 70\% for meadows,

$\mathrm{Vi}$-saturation degree within the initial bases.

$\mathrm{H}$-depth of the soil layer necessary to be amended: 25 $\mathrm{cm}$ for field crops and trees plantations -wine-growing plantations; $40 \mathrm{~cm}$ at creation of a tree plantations -winegrowing plantations and $10 \mathrm{~cm}$ for meadows.

0.06 - coefficient for recalculation in t/ha.

PNA - the power to neutralise the used amendment.

Using the above mentioned relation and the chemical characteristics of an albic - stagnic luvsoil, medium clay/ medium loamy clay (table 6), respectively change bases ( SB ) in the processed state (Ap) de 9.87 at me/100 gr sol, V\% de 55.24 the dolomite limestone has been calibrated (PNA=90), at a crop for field crops, this being of 10.36 t/ha.

For the shading Districambosoil, middle sandy clay/ medium clay (table 7) having SB (summed bases) in the first $10 \mathrm{~cm}$ of 6.20 at me/100 gr sol and V\% of 48.3 the dolomite calcar doses has been calleted (PNA $=90)$ for the usable category of meadow, this being for 1.85 t/ha.

The effects of the amendments have at their basis the reaction that is being produced within the colloidal complex of the soil and the lime powder passed into the solution (a more intense solubilisation in case of combining the calcification amendments with organic fertilisation).

Limestone:

$$
\begin{aligned}
& \mathrm{CaCO}_{3}+\mathrm{H}_{2} \mathrm{O}+\mathrm{CO}_{2} \rightarrow \mathrm{Ca}\left(\mathrm{HCO}_{3}\right)_{2} \text { which hydrolyzes alkaline } \\
& \mathrm{Ca}\left(\mathrm{HCO}_{3}\right)_{2}+2 \mathrm{HOH} \rightarrow \mathrm{Ca}^{3+}+2 \mathrm{OH}+2 \mathrm{H}_{2} \mathrm{CO}_{3} \\
& \mathrm{Sol} \mathrm{Al}^{3+}+2 \mathrm{Ca}^{3+}+4 \mathrm{OH} \rightarrow \underset{\left.\mathrm{SOl}^{+} \mathrm{Ca}^{3+}+\mathrm{Al}^{+} \mathrm{OH}\right)_{3}+\mathrm{H}_{2} \mathrm{O}}{\mathrm{Ca}^{3+}}
\end{aligned}
$$

Decreasing acidity, immobilizing exchangeable alumina, increasing the solubility and availability of phosphorus and potassium are the main changes in the amended soils and reasons for increasing fertility. From a biological point of view, an increase in the activity of fixing microorganisms of azote and nitrifying fixation microorganisms has been observed.

\section{Conclusions}

The knowledge of the natural conditions and especially of the ecological potential of the lands (defined according to MESP-ICPA Bucharest) for the main categories of use and crops is of particular importance in carrying out the qualitative evaluation of the lands and the analysis of the limiting factors, and has as main purpose to offer to specialists in agriculture a global picture of the phenomena that are taking place within the elementary units of the pedological landscape through which the overall strategy for the set of ameliorative measures will be shown.

In this framework, the determination of the land production capacity as well as the foundation of the improvement of these technologies improvement can constitute for the decision-maker (Government, Local Public Administration) an effective tool for choosing working procedures that favor the efficient use of the land resources within the researched area in accordance with the specific pedoclimatic conditions, for processing and selling agro-food products, thus proving itself an ecological and efficient solution for the future.

Systematic pedological and agrochemical mapping of the soils, conducted by the Pedological and Agrochemical Offices of our country offers valuable data concerning the evolution of the quality of soils, the establishment and application of crop technologies in a differentiated way, land assessement and establishment of favorability for different cultures, the establishment of land work for improvement and of ameliorative technologies, the organisation and systematisation of territory, which justifies the genuineness and necessity of continuing these activities.

\section{References}

1.BORCEAN I., TABARA V., DAVID GH., BORCEAN E.,TARAU D., BORCEAN A., Zonarea cultivarea si protectia plantelor de camp in Banat, 1996, Ed. Mirton Timisoara, p.11-18;

2.COLIBAS M., Solul-Apa- Planta, 2016, Ed. Mirton , Timisoara, p.111112 ;

3.DUMITRU M., STEFANESCU S.L., Scheme agroambientale in contextul dezvoltarii rurale, 2000, Stiinta solului nr. 2, vol. XXXIV, Ed. Signata, Timisoara,p. 121-126;

4. ${ }^{* * *}$ Arhiva O.S.P.A. Timisoara-Studii pedologice si agrochimice; 5.*** Metodologia elaborarii studiilor pedologice, vol. I, II si III, Redactia de propaganda agricola, 1987, Bucuresti;

6.FLOREA N., MUNTEANU I., cordon., The Romanian Soil Taxonomy System, Editura SITECH, Craiova, 2012, p.206;

7.TARAU D., ROGOBETE GH., GROZAV A., DICU D., Solurile din sudvestul Romaniei, 2018, Ed. Eurobit Timisoara, p. 134-139;

8.BORZA I., PUSCA I., TARAU D., Calitatea solurilor din Vestul Romaniei si rezultate ale aplicarii ingrasamintelor chimice pe soluri si la plante cu cerinte diferite, 2006, Lcr. St. Simp. International CIEC Romania Bacau, Ed. Agris Bucuresti, p.21-236; 
9.DAVID GH., TARAU D., SANDOR C.I., NITA L., Soil and climate factors that define land productivity in the lower plain of Banat, 2018, Conference Proceedings Volume18, Issue:3.2, Albena, Bulgaria, p.368372;

10.IANOS GH., PUSCA I., GOIAN M., Solurile Banatului (II) conditii naturale si fertilitate, 1997, Ed. Mirton, Timisoara, p.117-118;

11.NITA L., TARAU D., DICU D., ROGOBETE GH. DAVID GH., Land Bound of Banat, 2017 Research Journal of Agricultural Science, Facultatea de Agricultura,Vol. 49(3), Ed. Agroprint Timisoara, p. 74-80; 12.TARAU D., ROGOBETE GH., NITA L., DICU D., TUDOR C., RADUICA C., The role of pedologic information in definining land productivity in the mountain area of southern Banat, 2017, Stiinta Solului, p.78-83;
13.TEACI D., Bonitarea terenurilor agricole, 1980, Ed. Ceres, Bucuresti, p. 50-112

14.NITA, L., TARAU, D., ROGOBETE, GH., NITA, S., BERTICI, R., TUTA, SAS, I., SAS, I., DICU, D., The Role of Ecopedological Parameters in ManagementSustainability of Banat Lands, Rev. Chim.(Bucharest), 69, no. 3, 2018, p.688

15.ROGOBETE, GH., TARAU, D., Solurile si ameliorarea lor. Harta solurilor Banatului, 1997, Ed. Marineasa, Timisoara, p. 44-46.

$\overline{\text { Manuscript received: } 21.10 .2018}$ 